The Bangladesh Veterinarian (2015) 32 (1) : 27 - 34

\title{
Effects of breed, management system, milk yield and body weight on onset of postpartum ovarian cyclicity in cows
}

\author{
SN Saha, MGS Alam*, M Shamsuddin ${ }^{1}$ and M Khatun ${ }^{2}$ \\ Department of Surgery and Obstetrics, Faculty of Veterinary Science, Bangladesh \\ Agricultural University, Mymensingh-2202, Bangladesh
}

\begin{abstract}
To determine the factors affecting onset of postpartum ovarian cyclicity (PPOC) milk progesterone concentrations were measured in 84 cows. About $30 \%$ showed cyclicity within 120 days of parturition. Intensively managed cows started cyclicity earlier $(\mathrm{P}>0.05)$ than extensively managed animals. Holstein-Friesian crossbred cows started ovarian cyclicity earlier ( $80.2 \pm 17.5$ days) with higher proportion $(37.9 \%)$ than local zebu cows $(84.8 \pm 21.0$ days) and about $13.3 \%$, respectively $(\mathrm{P}>0.05)$. The cows yielding $4-12 \mathrm{~kg}$ milk/day required $73.5 \pm 10.0$ days to start ovarian function earlier than those producing $1-2 \mathrm{~kg} /$ day $(84.8 \pm 21.0$ days) (P>0.05). Cows with lower $(<200 \mathrm{~kg})$ and higher $(>300 \mathrm{~kg})$ body weights started ovarian activity by $81.6 \pm 16.6$ and $76.3 \pm 17.4$ days, respectively $(\mathrm{P}>0.05)$. Cows with lower body weight showed PPOC at lower rate $(5.2 \%)$ than those of medium $(38.3 \%)$ and higher body weight $(33.3 \%)(\mathrm{P}<0.05)$. The delayed onset of PPOC prolonged the calving interval. (Bangl. vet. 2015. Vol. 32, No. 1, 27 - 34)
\end{abstract}

\section{Introduction}

To achieve satisfactory economic benefit from the dairy industry, intercalving interval should not exceed 365 days (Haresign et al., 1983; Opsomer et al., 1996). Decrease in fertility is a major cause of economic loss with higher culling rate (Khatib et al., 2009). Prolonged interval (>85 days) between calving and onset of ovarian function is regarded as one of the most important reproductive problems (Coleman et al., 1985). Prolonged suppression due to negative feedback of progesterone secreted by the corpus luteum and the placenta during pregnancy causes the pituitary to be refractory at very early postpartum period (within 10-12 days) as indicated by lack of response to exogenous gonadotrophin-releasing hormone (Alam and Dobson, 1986). As a result of absence or very low output $(<1.0 \mathrm{ng} / \mathrm{mL})$ of gonadotrophin, the ovary is relatively quiescent and the cow remains anoestrous. Dietary energy supplementation hastens the onset of postpartum ovarian function (Lalman et al., 1997). Among various factors, management, nutrition, suckling, and body weight are the most important determinants of the initiation of cyclicity (Fitzpatrick, 1994). The present study was designed to investigate factors that may affect the onset of postpartum ovarian cyclicity in dairy cows.

1Technical Officer, Animal Production and Health Section, IAEA/FAO, Vienna, Austria

2Endeavour PhD Fellow, Dairy Research Group, C04, MC Franklin Laboratory, Faculty of Veterinary

Science, University of Sydney, Australia I 2570

*Corresponding author:- E-mail: mgsalam21@gmail.com 


\section{Materials and Methods}

\section{Experimental animals and their management}

Eighty-four lactating cows were selected at random: 30 were local zebu, 37 were crosses of Holstein-Friesian and 17 were crosses of Sahiwal or Sindhi with local zebus. Average milk yield was $3.8 \pm 2.4 \mathrm{~kg} /$ day, and estimated mean body weight at calving was $262.6 \pm 68.9 \mathrm{~kg}$. The body weight of the cows was estimated immediately after calving and every 10 days up to 120 days postpartum using a standardized tape from the Swedish Association for Livestock Breeding and Production, Eskilstuna, Sweden (Comb MAAl). The body condition of cows was scored (1-5 scale) following modification of the method of Nicholson and Butterworth (1986). All cows calved normally and had no history of periparturient diseases. The cows were apparently healthy and free from detectable abnormalities of the genital tract. Routine treatment against liver fluke and round worms was practised and the cows were vaccinated routinely against haemorrhagic septicaemia, anthrax, blackquarter and foot and mouth diseases. Twenty seven cows belonged to a commercial dairy farm where intensive management was practised, and the remaining 57 belonged to smallholders where the cows were managed extensively. In intensively managed farms, the cows were supplied with stall feed approximately $5 \mathrm{~kg}$ straw, $10-15 \mathrm{~kg}$ green grass and 3 - $5 \mathrm{~kg}$ concentrates per cow per day in two meals. In extensively managed smallholdings most cows were tethered and grazing for approximately eight hours daily. In addition to that in most farms, $5 \mathrm{~kg}$ straw was supplied to each cow daily. In both management systems, all cows had free access to drinking water. All cows were milked by hand with their calves present. In commercial dairy farms, the cows were milked twice daily at an interval of 8 hours and in smallholdings, most cows were milked once daily. In commercial dairy farms, milk yield was determined by interviewing the farmer or from the farm register.

\section{Progesterone radioimmunoassay (RIA)}

Skim milk was used for analysis of progesterone concentrations. Milk samples (10 $\mathrm{mL}$ ) were collected from each cow into tubes containing an $8 \mathrm{mg}$ sodium azide tablet (MERCK, Germany) at 10 day intervals starting at parturition until the animals showed signs of standing oestrus. The milk samples were centrifuged at room temperature for 15 minutes at $1000 \mathrm{~g}$ to remove fat before the skimmed milk was assayed for progesterone. The solid-phase-radioimmunoassay technique was used as described by the Joint FAO/IAEA Division, Vienna, Austria using 125I-labelled progesterone as the tracer (Shamsuddin et al., 2006). Progesterone profiles of $>3.0$ $\mathrm{nmol} / \mathrm{L}$ were considered to be of luteal origin. The intra and inter-assay coefficients of variation were $6.3 \%(n=13)$ and $9.0(n=3)$, respectively. The percentage binding at zero level was $31.0 \pm 2.3$, and the assay sensitivity was $0.6 \mathrm{nmol} / \mathrm{L}$.

\section{Statistical analysis}

All the recorded and calculated data were analysed using the SPSS statistical computer package for the analysis of variance. Results are given as means \pm standard 
error of mean. The data were analysed using the Student's $t$-test. The ANOVA was performed to compare data among selective groups.

\section{Results and Discussion}

Among 84 cows only $25(29.7 \%)$ started cycling (detected by measuring milk progesterone) within 120 days of parturition (Table 1). In this study, cyclic cows showed progesterone peak(s) before showing behavioural oestrus. This is an agreement with Claycomb et al. (1996). No cyclic cows showed a continuous low level of progesterone. Holstein-Friesian crossbred cows started postpartum ovarian cyclicity soonest $(80.2 \pm 17.5$ days; $\mathrm{n}=14)$ and local zebu cows started last $(84.8 \pm 21.0$ days; $\mathrm{n}=4)$. However, the difference between breeds was not significant $(\mathrm{P}>0.05)$. More Holstein-Friesian crossbred cows started ovarian cyclicity $(37.9 \% ; n=37)$ than, local zebu cows $(13.3 \% ; \mathrm{n}=30)$, but the difference was not significant $(\mathrm{P}>0.05)$. The milk yield, body condition score and body weight at calving were higher $(5.4 \pm 2.5$ $\mathrm{kg} /$ day, $2.8 \pm 0.4$ and $307.5 \pm 65.5 \mathrm{~kg}$, respectively) in Holstein-Friesian crossbred cows than in local zebu cows $(2.0 \pm 0.7 \mathrm{~kg} /$ day, $2.0 \pm 0.4$ and $206.7 \pm 38.0 \mathrm{~kg}$, respectively). Holstein-Friesian crossbred cows had higher BCS (2.8 \pm 0.4$)$ and body weight $(307.5 \pm 65.5 \mathrm{~kg}$ ) than other crossbreds (Sahiwal or Sindhi crossbred; BCS $2.5 \pm$ 0.6; body wt. $251.7 \pm 45.4 \mathrm{~kg}$ ) and local zebu cows (BCS $2.0 \pm 0.4$; body wt. $206.7 \pm 38.0$ $\mathrm{kg}$ ). The poorer performance of local zebu cows could be due to genetic differences (Darwash et al., 1996). Postpartum ovarian cyclicity and uterine involution take longer in some heavier breeds then in smaller dairy breeds (Sloos and Dutty, 1980). Fonseca et al. (1983) reported that high-producing Jersey cows ovulated earlier than HolsteinFriesian crosses. Shamsuddin et al. (1997) found that Sahiwal and their crosses showed lower fertility than Holstein-Friesian and their crosses with local zebu cows. Contrarily, Pereira et al. (1995) found no relationship between early postpartum ovarian cyclicity and breed. This may be due to better adaptation of local cows to the environment.

Table 2 shows that the cows reared under extensive management began postpartum ovarian cyclicity later $(88.1 \pm 20.0$ days; $\mathrm{n}=14)$ than those intensively managed $(73.5 \pm$ 10.0 days; $\mathrm{n}=11)$, but the difference was not significant $(\mathrm{P}>0.05)$. Fewer extensively managed cows showed postpartum ovarian cyclicity $(24.6 \% ; \mathrm{n}=57)$ than those managed intensively $(40.8 \% ; \mathrm{n}=27)$ but the difference was not significant $(\mathrm{P}>0.05)$. The milk yield, body condition score at calving and body weight at calving were higher $(6.3 \pm 2.4 \mathrm{~kg} /$ day, $2.9 \pm 0.4$ and $319.4 \pm 63.0 \mathrm{~kg}$, respectively) in intensively managed cows than those extensively managed $(2.6 \pm 1.0 \mathrm{~kg}, 2.2 \pm 0.6$ and $232.2 \pm 51.4$ $\mathrm{kg}$, respectively). Intensively managed cows with adequate diet and proper health care, can produce optimum reproductive performance (Laben et al., 1982). On the contrary, Peters (1984) stated that in spite of good management some cows show inferior reproductive performance. This may be due to variation to adaptation to the environment. Reasonable energy balance is necessary at calving of first lactating cows; otherwise ovulation was delayed, impairing subsequent reproductive performance (Samarütel et al., 2006). Poor management might influence the hypothalamo-pituitary ovarian system and thereby delay postpartum cyclicity (Morrow et al., 1989). 
Fitzpatrick (1994) found that cows managed semi-intensively showed longer postpartum period than cows in free range systems. The cows managed intensively started cyclicity earlier, when provided with proper veterinary care, routine anthelmintic treatment and feed supplementation. Controlled temperature and humidity influenced the resumption of cyclicity. Extensively managed cows did not have feed supplementation.

The effects of milk yield on onset of postpartum cyclicity are presented in Table 3. Cows with higher milk yield (4-12 kg/day) started postpartum cyclicity earlier $(73.5 \pm$ 10.0 days; $\mathrm{n}=11)$ than those with lower yield $(1-2 \mathrm{~kg} /$ day $)(84.8 \pm 21.0$ day; $\mathrm{n}=4)$ or medium yield $(2-4 \mathrm{~kg} /$ day $)(89.4 \pm 20.6$ days; $\mathrm{n}=10)$ but the differences were not significant $(\mathrm{P}>0.05)$. More crossbred cows with higher milk yield began postpartum ovarian cyclicity $(40.3 \% ; n=26)$ earlier than low-yielding cows $(16.7 \% ; n=24)$ but the difference was not significant $(\mathrm{P}>0.05)$. Highest body condition score and body weight at calving (3.1 \pm 0.3 and $322.3 \pm 56.1 \mathrm{~kg}$, respectively) were recorded in high-yielding cows and lowest $(1.8 \pm 0.4$ and $196.9 \pm 26.4 \mathrm{~kg}$, respectively) in low-yielding cows. There is a negative correlation between high milk yield and subsequent reproductive performance (Darwash et al., 1996). Long acyclic period with ovarian dysfunction was observed in high-yielding cows, similar to the results of Kumar et al. (2009). Cows with ovarian cysts and/or increased peak milk production had significantly longer calving-to-first oestrus and calving-to-conception intervals as well as lower conception rates than average producing cows without cysts (Kinsel and Etherington, 1998). Differences in plasma concentrations of $\mathrm{LH}$, progesterone and prostaglandin $\mathrm{F}_{2 \alpha}$ were reported by Eley et al. (1981). However, Fonseca et al. (1983) and Darwash et al. (1996) observed that high-producing cows with positive energy balance ovulated earlier than lower-producing herd mates. On the contrary, high milk production may result in delayed postpartum cyclicity (Kluezek and Traczykaski, 1987). Short dry periods resulted in fewer days open in the subsequent lactation; however, this was entirely due to the lower milk yield associated with shortened dry periods (Kuhn et al., 2007). No significant differences between high and low yielding cows were observed by Harrison et al. (1990). Cows producing less milk were mostly local and managed extensively and were being used for many purposes.

Cows $(\mathrm{n}=59)$ with lower body weight $(252-200 \mathrm{~kg})$ at calving started postpartum ovarian cyclicity at a mean of 115 days (Table-4). On the contrary, cows $(n=6)$ with higher body weight $(301-455 \mathrm{~kg}$ ) at calving started postpartum ovarian cyclicity 76.3 \pm 17.4 days after calving (Table 4). These cows started their ovarian cyclicity between 60 and 115 days postpartum. Eighteen cows weighing 201-300 kg at calving started their postpartum cyclicity earlier $81.6 \pm 16.6$ days than the cow with body weight 301 $455 \mathrm{~kg}$, and 59 with the body weight $115-200 \mathrm{~kg}$. The daily milk yield and body condition score at calving were highest $(6.0 \pm 2.4 \mathrm{~kg}$ and $3.0 \pm 0.4$, respectively) in cows of high body weight at calving but lower $(2.0 \pm 0.9 \mathrm{~kg}$ and $1.8 \pm 0.5$, respectively) in cows with low body weight at calving. Energy balance and body weight play an important role in determining the postpartum interval to $1^{\text {st }}$ ovulation and subsequent fertility (Britt, 1995). Doren et al. (1986) demonstrated a weight change of the cow from conception until parturition was more closely associated with days postpartum to conception than birth weight. Richards et al. (1986) and Roche et al. (2007) reported 
negative impact of poor BCS on return to oestrus. Dietary restriction during late pregnancy results in weight loss and decrease in body fat reserve, and delays return to oestrus postpartum (Dziuk and Bellows, 1983), but Richards et al. (1986) stated that both pre and postpartum dietary restriction of feed supplementation causes weight loss and decreased body fat at calving, which ultimately reduces the reproductive efficiency of cows. Cows which, had gained body weight following calving began their ovarian cyclicity earlier (Pleasants and Barton, 1992). Weight gain within 60 days of normal parturition resulted in earlier onset of oestrus. Cows that lose body weight after parturition have impaired reproductive performance, and this could be due to genetics, diseases and undernourished condition (Spitzer et al., 1995). PérezHernández et al. (2002) stated that delaying suckling for 8 hours after milking increases the proportion of cows ovulating within 100 days of calving, shortened the calving to first ovulation interval and improved calf performance without adversely affecting cow's milk yield or body weight change.

Table 1: Effects of breed on onset of postpartum ovarian cyclicity in cows

\begin{tabular}{|c|c|c|c|c|c|}
\hline Breeds & $\begin{array}{c}\text { Onset of } \\
\text { ovarian } \\
\text { cyclicity (days) }\end{array}$ & $\begin{array}{c}\% \text { onset of } \\
\text { ovarian } \\
\text { cyclicity }\end{array}$ & $\begin{array}{l}\text { Milk yield } \\
\text { per day }\end{array}$ & $\begin{array}{l}\text { Body condition } \\
\text { score at calving }\end{array}$ & $\begin{array}{l}\text { Body weight } \\
\text { at calving }\end{array}$ \\
\hline Local zebu & $\begin{array}{c}84.8 \pm 21.0 \\
(\mathrm{n}=4)\end{array}$ & $13.3(n=30)$ & $\begin{array}{l}2.0 \pm 0.7 \\
(\mathrm{n}=30)\end{array}$ & $\begin{array}{l}2.0 \pm 0.4 \\
(\mathrm{n}=30)\end{array}$ & $\begin{array}{c}206.7 \pm 38.0 \\
(\mathrm{n}=30)\end{array}$ \\
\hline $\begin{array}{l}\text { Holstein- } \\
\text { Friesian } x \\
\text { local zebu }\end{array}$ & $\begin{array}{c}80.2 \pm 17.5 \\
(\mathrm{n}=14)\end{array}$ & $37.9(\mathrm{n}=37)$ & $\begin{array}{l}5.4 \pm 2.5 \\
(\mathrm{n}=37)\end{array}$ & $\begin{array}{l}2.8 \pm 0.4 \\
(\mathrm{n}=37)\end{array}$ & $\begin{array}{c}307.5 \pm 65.5 \\
(\mathrm{n}=37)\end{array}$ \\
\hline $\begin{array}{l}\text { Sahiwal/ } \\
\text { Sindhi x } \\
\text { local zebu }\end{array}$ & $\begin{array}{c}82.9 \pm 18.8 \\
(n=7)\end{array}$ & $18.8(\mathrm{n}=17)$ & $\begin{array}{l}3.6 \pm 1.6 \\
(\mathrm{n}=17)\end{array}$ & $\begin{array}{l}2.5 \pm 0.6 \\
(n=17)\end{array}$ & $\begin{array}{c}251.7 \pm 45.4 \\
(\mathrm{n}=17)\end{array}$ \\
\hline
\end{tabular}

The difference in the rate of onset of cyclicity between breeds was not significant $(\mathrm{P}>0.05)$

Table 2: Effects of management on the onset of postpartum ovarian cyclicity in cows

\begin{tabular}{l|c|c|c|c|c}
\hline Management & $\begin{array}{c}\text { Onset of } \\
\text { ovarian cyclicity } \\
\text { (days) }\end{array}$ & $\begin{array}{c}\text { \% onset of } \\
\text { ovarian } \\
\text { cyclicity }\end{array}$ & $\begin{array}{c}\text { Milk yield } \\
\text { per day }\end{array}$ & $\begin{array}{c}\text { Body condition } \\
\text { score at } \\
\text { calving }\end{array}$ & $\begin{array}{c}\text { Body wt. at } \\
\text { calving }(\mathrm{kg})\end{array}$ \\
\hline Extensive & $88.1 \pm 20$ & 24.6 & $2.6 \pm 1.0$ & $2.2 \pm 0.6$ & $232.2 \pm 51.4$ \\
& $(\mathrm{n}=14)$ & $(\mathrm{n}=57)$ & $(\mathrm{n}=57)$ & $(\mathrm{n}=57)$ & $(\mathrm{n}=57)$ \\
Intensive & $73.5 \pm 10$ & 40.8 & $6.3 \pm 2.4$ & $2.9 \pm 0.4$ & $319.4 \pm 3.0$ \\
& $(\mathrm{n}=11)$ & $(\mathrm{n}=27)$ & $(\mathrm{n}=27)$ & $(\mathrm{n}=27)$ & $(\mathrm{n}=27)$ \\
\hline
\end{tabular}

Cows managed intensively were heavier $(201-300 \mathrm{~kg})$, produced more milk and showed postpartum ovarian cyclicity earlier. The Holstein-Friesian crossbred cycled earlier and at high rate. Holstein-Friesian crossbred cows can be introduced in an intensive farming system with proper management and health care, otherwise it would be very difficult to achieve a calving interval of 365 days. 
Table 3: Effects of milk yield on onset of postpartum ovarian cyclicity in cows

\begin{tabular}{l|c|c|c|c}
\hline $\begin{array}{c}\text { Milk } \\
\text { yield }(\mathrm{kg})\end{array}$ & $\begin{array}{c}\text { Onset of ovarian } \\
\text { cyclicity (days) }\end{array}$ & $\begin{array}{c}\text { \% onset of } \\
\text { ovarian cyclicity }\end{array}$ & $\begin{array}{c}\text { Milk yield per } \\
\text { day }\end{array}$ & $\begin{array}{c}\text { Body weight at } \\
\text { calving }\end{array}$ \\
\hline $1-2$ & $84.8 \pm 21.0(\mathrm{n}=4)$ & $16.7(\mathrm{n}=24)$ & $1.8 \pm 0.4(\mathrm{n}=24)$ & $196.9 \pm 26.4(\mathrm{n}=24)$ \\
$3-4$ & $89.4 \pm 20.6(\mathrm{n}=10)$ & $29.4(\mathrm{n}=34)$ & $2.4 \pm 0.4(\mathrm{n}=34)$ & $257 \pm 54.7(\mathrm{n}=34)$ \\
$5-12$ & $73.5 \pm 10.0(\mathrm{n}=11)$ & $40.3(\mathrm{n}=26)$ & $3.1 \pm 0.3(\mathrm{n}=26)$ & $322.0 \pm 56.1(\mathrm{n}=26)$ \\
\hline
\end{tabular}

Table 4: Effects of body weight at calving on onset of postpartum ovarian cyclicity in cows

\begin{tabular}{l|c|c|c|c}
\hline $\begin{array}{c}\text { Body wt. at } \\
\text { calving }(\mathrm{kg})\end{array}$ & $\begin{array}{c}\text { Onset of ovarian } \\
\text { cyclicity (days })\end{array}$ & $\begin{array}{c}\text { \% onset of } \\
\text { ovarian cyclicity }\end{array}$ & $\begin{array}{c}\text { Milk yield } \\
(\mathrm{kg} / \text { day })\end{array}$ & $\begin{array}{c}\text { Body condition } \\
\text { score at calving }\end{array}$ \\
\hline $152-200$ & $115.0^{\mathrm{b}}(\mathrm{n}=59)$ & $5.2^{\mathrm{a}}(\mathrm{n}=19)$ & $2.1 \pm 0.9(\mathrm{n}=19)$ & $1.8 \pm 0.5(\mathrm{n}=19)$ \\
$201-300$ & $81.6 \pm 16.6^{\mathrm{ab}}(\mathrm{n}=18)$ & $38.3^{\mathrm{b}}(\mathrm{n}=47)$ & $3.7 \pm 2.1(\mathrm{n}=47)$ & $2.5 \pm 0.5(\mathrm{n}=47)$ \\
$301-455$ & $76.3 \pm 17.4^{\mathrm{ab}}(\mathrm{n}=6)$ & $33.3^{\mathrm{ab}}(\mathrm{n}=18)$ & $6.0 \pm 2.4(\mathrm{n}=18)$ & $3.0 \pm 0.4(\mathrm{n}=18)$ \\
\hline
\end{tabular}

$\mathrm{n}=$ number of animals; $\mathrm{a}, \mathrm{b}$ values with different superscripts differ significantly from each other $(\mathrm{P}<0.05)$

Body weight at calving is an important determinant for the onset of postpartum ovarian cyclicity. In this study, cows started their ovarian cyclicity within four months of parturition where intensively management systems were practised. On the other hand, cows producing less milk were mostly local and managed extensively and being used for many purposes, had poor postpartum reproductive performance.

\section{Conclusions}

Based on the range of performances, the factors with the greatest potential influence on the initiation of ovarian activity after calving were good body condition at calving. It is suggested that Holstein-Friesian crosses is the best choice of animals to improve milk production in a near-tropical environment like Bangladesh. They hate the heat, their reproduction is awful and their maintenance costs are disproportionally high to the amount of milk that they can produce from forages (Rendel and Hickman, 1978).

\section{References}

Alam MGS, Dobson H 1986: Postpartum release of prostaglandin $\mathrm{F}_{2}$ alpha $\left(\mathrm{PGF}_{2} \mathrm{alpha}\right)$ and the effect of oestradiol benzoate on the concentrations of $\mathrm{PGF}_{2}$ alpha. Bangladesh Veterinary Journal 2 73-81.

Barton BA, Rosario HA, Anders-omn GW, Graindle BP, Carroll DJ 1996: Effects of dietary crude protein, breed, parity and health status on the fertility in dairy cows. Journal of Dairy Science 79 2225-2236.

Britt JH 1995: Relationships between postpartum nutrition, weight loss and fertility. Cattle Practice 3 79-83.

Claycomb RW, Delwiche MJ, Munro CJ, BOnDurant RH 1996: Enzyme immunoassay for on line sensing of milk progesterone. Transactions of the ASAE 39 719-734. 
Coleman DA, Thayne WV, Dailey RA 1985: Factors affecting reproductive performance of dairy cows. Journal of Dairy Science 58 1793-1803.

Darwash AO, Lamming GE, Wolliams JA 1996: Estimation of genetic variation in the interval from calving to postpartum ovulation and traditional measures of fertility in dairy cattle. British Society of Animal Science 65 9-16.

Doren PE, Long CR, Cartwright TC 1986: Factors affecting the relationship between calving intervals of cows and weaning weights of calves. Journal of Animal Science 62 1194-1202.

Dziuk PJ, Bellows RW 1993: Management of reproduction in beef cattle, sheep and pig. Journal of Animal Science 57 355-360.

Eley DS, Thatcher WW, Head HH, Collier RJ, Wilcox CJ, Call EP 1981: Pre-parturient and post-parturient endocrine changes of conceptus and maternal units in Jersey cows bred for milk yield. Journal of Dairy Science 64 312-320.

Fitzpatrick LA 1994: Advances in the understanding of postpartum anoestrus Bos indicus cows. Proceeding: Final Research Co-ordination meeting FAO/IAEA Co-ordinated Research Programme, Bangkok, Thailand, 1-5 February. pp. 19-35.

Fonseca FA, Britt JH, McDaniel BT, Wilk JC, Rakes AH 1983: Reproductive traits of Holsteins and Jerseys. Effects of age, milk yield and clinical abnormalities on involution of cervix and uterus, ovulations, oestrous cycles, detection of oestrus, conception rate and days open. Journal of Dairy Science 66 1128-1147.

Haresign W, Foxcroft GR, Lamming GE 1983: Control of ovulation in farm animals. Journal of Reproduction and Fertility 69 383-395.

Harrison ROP, Frod SP, Young JW, Conley, Freeman AJ 1990: Increased milk yield versus reproductive and energy status of high producing dairy cows. Journal Dairy Science $\mathbf{7 3}$ 27-49.

Khatib H, Huang W, Wang X, Tran AH, Bindrim AB, Schutzkus V, Monson RL, Yandell BS 2009: Single gene and gene interaction effects on fertilization and embryonic survival rates in cattle. Journal of Dairy Science 92 2238-2247.

Kinsel ML, Etherington WG 1998: Factors affecting reproductive performance in Ontario dairy herds. Theriogenology 50 1221-1238.

Kluezek JP, Traczykaski A 1987: Effect of environmental conditions on fertility and yield of milk cow. Animal Breeding Abstract 552070.

Kuhn MT, Hutchison JL, Norman HD 2007: Dry period length in US Jerseys: characterization and effects on performance. Journal of Dairy Science 90 2069-2081.

Kumar SH, Nakao T, Higaki T, Suzuki T, Akita M 2009: Resumption of postpartum ovarian cyclicity in high-producing Holstein cows. Theriogenology 61 637-649.

Laben RJ, Shanks R, Borger PJ, Freeman AE 1982: Factor affecting milk yield and reproductive performance. Journal of Dairy Science 65 1004-1015.

Lalman DL, Keisler DH, Williams JE, Scholljegerdes EJ, Mallett DM 1997: Influence of post-partum weight and body condition change on duration of anoestrus by under nourished suckled beef heifers. Journal of Animal Science 15 2003-2008. 
Morrow DA, Robert RJ, McEntee K, Gray HG 1989: Postpartum ovarian activity and uterine involution in dairy cattle. Journal of American Veterinary Medical Association 149 1596-1609.

Nicholson MJ, Butterworth MH 1986: A guide to condition scoring of Zebu Cattle. International Livestock Center for Africa, Addis Abba, Ethiopia. pp. 29.

Opsomer G, Mijtem P, Coryn M, Kruif A De 1996: Post-partum anoestrus in dairy cows, a review. Veterinary Quarterly 18 68-75.

Pereira MN, Silva HM, Reis RB 1995: Effect of management on reproductive performance in a dairy herd. Arquivo-Brasileiro-de-Medicina-Veterinaria-e-d-Zootecnia 47 181-190.

Pérez-Hernández P, García-Winder M, Gallegos-Sánchez J 2002: Postpartum anoestrus is reduced by increasing the within-day milking to suckling interval in dual purpose cows. Animal Reproduction Science 73 159-168.

Peters AR 1984: Reproductive activity of the cow in the post-partum period I. Factors affecting cow: An endocrine model. Veterinary Record 118 236-239.

Pleasants AB, Barton RA 1992: Observations on the postpartum oestrous cycles and their relationships to other reproductive years. New Zealand Journal of Agricultural Research 35 59-62.

Rendel J, Hickman CG 1978: World trends in cattle production and breeding. FAO Symposium on optimum methods of cattle breeding for increasing meat and dairy production, Warsaw, 29 May - 2 June.

Richards MW, Spitzer JC, Warner MB 1986: Effect of varying levels of postpartum nutrition and body condition at calving on subsequent reproductive performance in beef cattle. Journal of Animal Science 62 300-306.

Roche JR, Macdonald KA, Burke CR, Lee JM, Berry DP 2007: Associations among body condition score, body weight, and reproductive performance in seasonal-calving dairy cattle. Journal of Dairy Science 90 76-91.

Samarütel J, Ling K, Jaakson H, Kaart T, Kärt O 2006: Effect of body condition score at parturition on the production performance, fertility and culling in primiparous Estonian Holstein cows. Veterinarija IR Zootechnika T 36 69-74.

Shamsuddin M, Bhuiyan MMU, Chanda PK, Alam MGS, Abedin J 1997: Fertility related factors at Artificial insemination in cattle in Bangladesh. Proceeding: Bangladesh Society for Veterinary Education and Research (BSVER), Symposium on Reproductive Health Management in Ruminants, Bangladesh Agricultural University, Mymensingh, Publication No. 9 21-33.

Shamsuddin M, Bhuiyan MMU, Chanda PK, Alam MGS, Galloway D 2006: Radioimmunoassay of milk progesterone as a tool for fertility control in smallholder dairy farms. Tropical Animal Health and Production 38 85-92.

Sloos V and Dutty JH 1980: In: Handbook of bovine obstetrics. $2^{\text {nd }}$ edn. Williams and Willins Baltimore, USA pp. 81-86.

Spitzer JO, Morrison DG, Wettemann RP, Faulkner LC 1995: Reproductive responses and calf birth and weaning weights as affected by body condition at parturition and postpartum weight gain in primiparous beef cows. Journal of Animal Science 73 1251-1257. 